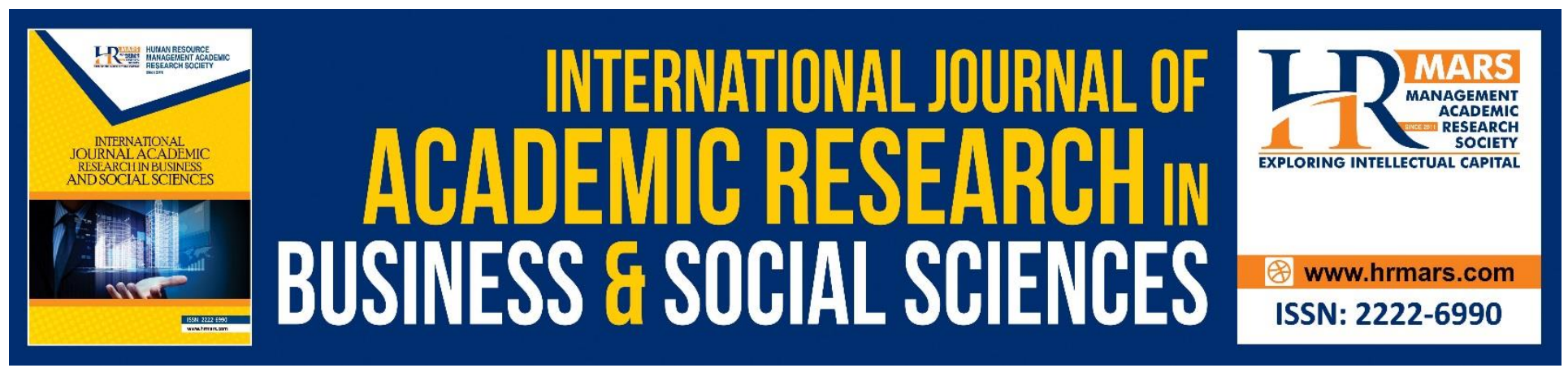

\title{
Influence of Informal Groups on Productivity: A Case Study on Philadelphia Pharmaceuticals Company
}

\section{Anas Abdulbaset Abbas}

To Link this Article: http://dx.doi.org/10.6007/IJARBSS/v8-i7/4384

DOI: $\quad 10.6007 /$ IJARBSS/v8-i7/4384

Received: 09 July 2018, Revised: 23 July 2018, Accepted: 29 July 2018

Published Online: 08 August 2018

In-Text Citation: (Abbas, 2018)

To Cite this Article: Abbas, A. A. (2018). Influence of Informal Groups on Productivity: A Case Study on Philadelphia Pharmaceuticals Company. International Journal of Academic Research in Business and Social Sciences, 8(7), 421-435.

Copyright: (C) 2018 The Author(s)

Published by Human Resource Management Academic Research Society (www.hrmars.com)

This article is published under the Creative Commons Attribution (CC BY 4.0) license. Anyone may reproduce, distribute, translate and create derivative works of this article (for both commercial and non-commercial purposes), subject to full attribution to the original publication and authors. The full terms of this license may be seen at: http://creativecommons.org/licences/by/4.0/legalcode

\section{Vol. 8, No. 7, July 2018, Pg. 421 - 435}

Full Terms \& Conditions of access and use can be found at http://hrmars.com/index.php/pages/detail/publication-ethics 


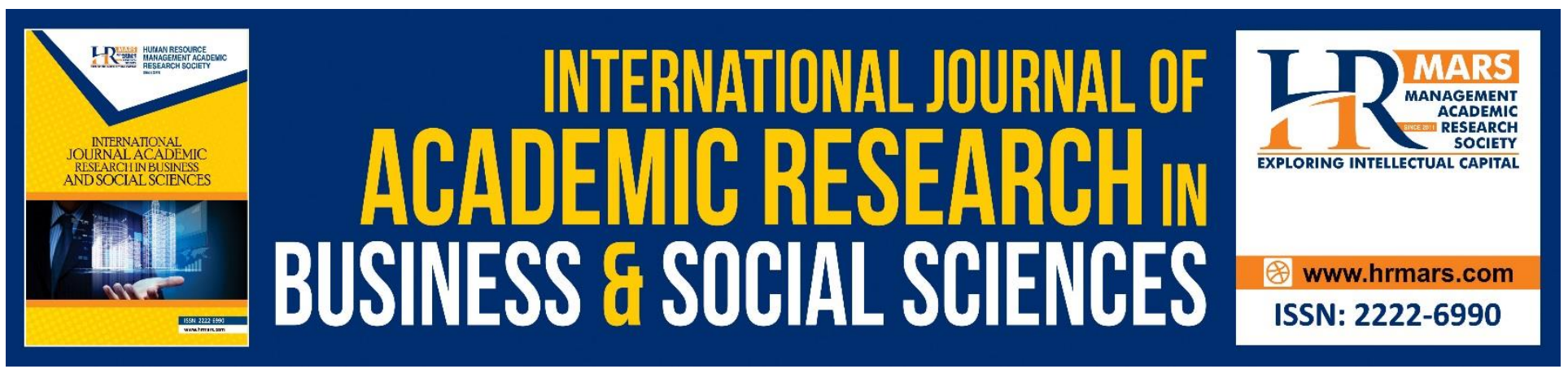

\title{
Influence of Informal Groups on Productivity: A Case Study on Philadelphia Pharmaceuticals Company
}

\author{
Anas Abdulbaset Abbas \\ Prince Sattam Bin Abdulaziz University, College of Science and Humanities Studies, Business \\ Administration Department, Kingdom of Saudi Arabia
}

\begin{abstract}
In the contemporary context of human resource management, workplace performance is seen to have a greater impact on the productivity and sustainability of employees. Accordingly, one of the areas that have been noted to affect the workplace performance is inter-professional collaboration among the workers within companies. While much attention is given to the formal groups that affect the very context of productivity among the workers, little is known on the influence of the informal groups on workplace performance. This descriptive case study unveils some of the critical impact that engagement of workers in informal groups on their productivity. Instinctively, the analysis investigates 48 workers from Philadelphia Pharmaceuticals and uses both questionnaires and semistructured interviews to collect the data. The results shows that out of the 48 participants investigated, $54.17 \%$ of them agrees that the informal groups enhances communication among the members while $27 \%$ noted that they find it easy to express their grievances in the informal setting. The results also confirmed that informal groups have no rules $(52.08 \%)$ hence high sense of autonomy is expected in an informal setting. Lastly, approximately $61.42 \%$ of the participants agreed to the fact that informal groups have a positive effect on the productivity of the members of staff with keen attention creating a high level of motivation among them. Those who did not support this fact noted that joining these informal groups could lead to strikes that might impede the proper functionality of the organizational structure hence would reduce productivity. It is recommended from this analysis that companies should encourage the workers' involvement in informal groups.
\end{abstract}

Keywords: Informal Groups, Productivity, Employee Motivation, Workplace Performance, Staff Affiliation

\section{Introduction}

According to Thibaut (2017) informal groups are the building blocks in an organization. In today's dynamic institutions, collaboration between all stake holders in an institution forms the basis for development within the firm and ensures that the management framework is able to create a platform for higher performance. An employee network is vital and a tool whose significance cannot be overlooked (Kukenberger, Mathieu, \& Ruddy, 2015). In decision making, employee participation determines whether the business succeeds or not by ensuring proper motivation and coordination 
of activities across the organizational structure. To keep standards and maintain efficiency, it is necessary for managers to look keenly, understand and appreciate teams and groupings within the firm. Harris \& Sherblom (2018) noted that being affiliated with one group or another is quite critical especially when dealing with management of employee attitude. The non-official groups in which the employees in an organization are associated determines the various aspects of their working capabilities (Marsick, \& Watkins, 2015). These transcends from motivation, development of skills to the notion of adherence to the standards of the firm and workplace procedures. In accordance with Mueller (2015) 92\% of those they interviewed indicated that getting affiliated to the various interest groups usually gives them some sense of belonging hence they feel motivated as they work with those in the same group. There is however little literature on the how these informal groups at workplace affect the very productivity of the employees across organizations. This investigation keen looks into this issue with keen attention to how the informal groups could be utilized to enhance the performance of a firm by finding the connection between the latter and the employee productivity. Informal groups are as real as the official affiliations in every organization and they normally act independently. These groups actually have their own management styles, norms and structures. They show cohesion and support for one another within and without the firm. When they oppose a policy, they work against it and may cause downfall of a whole firm. Properly thought out reforms and changes materialize if and only if they are endorsed by these informal groups. Locke (2015) pointed out that the informal groups formulate their own code of ethics or an unspoken set of standards. They can therefore be the engine that drives the formal policies, procedures, and plans of the entire firm. Many organizations fail despite having trained workforce, modern equipment and huge financial muscles. It therefore goes without say that human resource management is as vital as the management of other resources who carry out the day to day running of the institution (Hall, Frink, \& Buckley, 2017). In this investigation, a particular case study is done on Philadelphia Pharmaceuticals in which their employees are analyzed on how their productivity is affected by the notion of involvement into various informal groups.

\section{Objectives of the Study}

In this investigation, the major aim is to understand the influence that the informal groups have on the productivity of various employees in the Philadelphia Pharmaceuticals Company. Accordingly, the analysis aims at understanding the relationship between the management in the organization and the informal groups. The investigation of these relationships is to help understand how best these employees could be influenced to ensure that the organizational success is achieved. Another critical aim is to understand and discover the crucial contribution of the informal groups in the realization of the objectives of the organization in question. In most cases, the various informal groups such as trade unions and Sacco have been demystified as bringing disruptions in the normal processes of the organization while the same time there has been research that leans towards praising these groups for improving the workplace performance (Dweck, 2017). Through quantitative case study, this investigation analyzes the real connection between productivity and the notion of involvement into informal groups which indeed has a far reaching effect on streamlining the workforce into attaining the much needed organizational success. 
INTERNATIONAL JOURNAL OF ACADEMIC RESEARCH IN BUSINESS AND SOCIAL SCIENCES Vol. 8, No. 7, July 2018, E-ISSN: 2222-6990 @ 2018 HRMARS

\section{Summarized Research Questions}

$>$ What are some of the reasons for engaging in informal groups at workplace among the Philadelphia Pharmaceuticals Company staff?

$>$ What are some of the characteristics of Informal groups formed by the Philadelphia Pharmaceuticals?

$>$ What impact does the informal groups formed by the Philadelphia Pharmaceuticals company employees have on their productivity?

\section{Literature Review}

Informal groups are spontaneous teaming of individuals that commence naturally instigated to respond to a common interest of the entire membership which can easily point to the goals or independent activities of the team. Kohli, Blitzer, Lefco, Barter, Haynes, Colalillo, \& Zink, (2018) confirmed that these groups perform certain desired functions to their members such as; need for affiliation, desire to belong and build self-respect, senses of security, desire to fulfill their norms, right to information, desire for innovation and inventiveness by individuals. As Lloyd \& Mertens (2018) puts it, organizations need to be both effective and efficient. Effective according to him means, meeting organizational goals in a timely way. Likewise, efficient in his opinion means the degree to which the organization can satisfy the motive of its employees. Accordingly, the mission of a firm will come to full fruition and the managers will be accepted when the employees feel that the organization has them at heart hence geared towards their wellbeing (Parijat \& Bagga 2014). This theory rests upon the fact that the legitimacy of a manager is pegged on the junior officer's acceptance of his role to give orders and to be honored. De Vito, Brown, Bannister, Cianci \& Mujtaba (2018) note that when the managers and the subordinate staff engage in an informal setting, they are deemed to get acquainted with behavior and the personality traits of these managers and hence making it quite easy to interact with them. One of the reasons why people engage in informal groups within work settings is to have some sense of belonging (Cheavens, Cukrowicz, Hansen, \& Mitchell, 2016). This notion allows for growth of social ties and high level of respect among workers. (Ma, Batterham, Calear, \& Han, 2016) confirm that in the event that these employees have one informal group with the manager, it would be quite easy to accept the authority and instinctively obey the instructions of their superiors. In the words of Hughes, Rigtering, Covin, Bouncken \& Kraus (2018) "The organizational restructuring helps you get the most from people by developing a plan for corporate restructuring, layoffs and mergers." For an organization to develop, they must undergo structural adjustment in terms of their policies statement, technology and procedures. Employees must therefore be allowed to exploit their full potential and this can only be made possible through interactions within these social groupings.

\section{Theoretical Perspectives}

Several theories have been put forward to explain the influence of informal groups to the productivity of a firm. Such theories include:

\section{Balance Theory}

According to Brown, Gray, McHardy \& Taylor (2015), the theory posits that people get attracted towards each other on the basis of similar attitudes and common behavior they carry towards given set of objectives or goals. This theory acknowledges that there will be different people with varied thoughts within the organization (Jackson, 2018). It is now upon the managers to bring such people 
INTERNATIONAL JOURNAL OF ACADEMIC RESEARCH IN BUSINESS AND SOCIAL SCIENCES Vol. 8, No. 7, July 2018, E-ISSN: 2222-6990 @ 2018 HRMARS

together to realize the organizations goals. In as much as different groups exist within a firm; the managers must be peace makers in order to unite the different factions (Weller, Castanelli, Chen, \& Jolly, 2017). Therefore, the risks will not exist and this peaceful coexistence will create harmony and teamwork. The result will be evident in the scale of production that will be realized which indeed would be high. In the organization, positive relationship leads to positive result hence managers who work closely with employees will identify people who are goal oriented and motivate them for the work done by promotion and appraisal (Jackson, 2018). This will promote mutual relationship that will make the organization realize its goals through team work. Through inception of informal groups, the managers are able to exceptionally understand the very attitudes, perceptions and personality traits of various employees (Peacock, 2015). In so doing, the manager will create a balance among these employees that would eventually lead to high levels of work performance within the firm. Barends, Janssen \& Velghe (2016) additionally posit that in order to have a well-coordinated and functioning team, it would be proper for the managers to understand the capability and the weakness of every employee in order to ensure that they use their potential to the maximum for the benefit of the organization. Coming up with profound management strategies is bestowed upon the proper functionality of the workforce in place. In this context, the issues such as inter-professional collaborations and coordination of workplace operations is based on how effective the informal groups are in envisaging the very potential of each employee within the management framework to ensure that they are appropriately positioned for the attainment of the success within a firm (Friebel, Heinz, \& Zubanov, 2016).

\section{Interpersonal Theory and Behavior}

The theory states that individuals who have never met, but now come into contact regularly become attracted to each other as they become used to one another. One feels friendlier to a person he or she met in pleasant and undisturbing environment. When people have common features and values, they are drawn towards each other. (Weller, Castanelli, Chen, \& Jolly, 2017) assert that the major reason why people engage in informal groupings is for the need for security, protection and communication. Therefore, having an informal group not ensure highly effective communication within the company but it will also ensure that the employee feel secure and protected. Informal groups such as society credit and savings cooperatives for example, usually helps these employees to have financial security in the event that they get laid off in which they are deemed to get some good financial backup. In areas demanding control, for instance competition, dominance, survival for the fittest, self-esteem, people tend to link up with their opposite sexes.

According to Van den Broeck, Ferris, Chang \& Rosen (2016) individuals have their goals while working in an institution and attainment of such goals is bestowed upon the effectiveness of the informal groups they fall. When such people are motivated to set goals together, formulate an appropriate feedback mechanism their contribution will be higher. Interpersonal relationship enables free flow of information in the organization. Employees can therefore get clarifications hence regulate goal attainment difficulties. It enhances team work and employee's participation through total member involvement and commitment. It is an avenue through which the bottom-top approach of management can be achieved in an organization. This gives the employees a sense of belonging and participation (Weller, Castanelli, Chen, \& Jolly, 2017). They can now be identified with the level of output by the firm hence improving productivity. This is made possible due to the high level of commitment that will be seen from such employees who took part in the decision-making process. The success of today's organization goes along with the employees networking and collaboration. 
INTERNATIONAL JOURNAL OF ACADEMIC RESEARCH IN BUSINESS AND SOCIAL SCIENCES

Vol. 8, No. 7, July 2018, E-ISSN: 2222-6990 @ 2018 HRMARS

\section{McClelland's Need Theory}

According to McClelland (2015) people who acquire particular need behave differently with those who do not have. His theory is based on Murray's three needs; Achievement, power and affiliation. He found that people will group themselves based on their targets in an organization. There are those with the need for higher achievement, hence eventually performing better than those with low needs (Weller, Castanelli, Chen, \& Jolly, 2017). McClelland realized that those with high needs for achievement have the following characteristics:

a). Have strong desire to assume personal responsibility for performing a task or finding a solution to a problem.

b). They tend to set higher goals and take viable risks.

c). They are performance and feedback oriented.

d). they normally have desire for power.

With these features, such individuals are the backbone of the organization. They normally work hard and must be engaged at all time steer the firm towards achieving its goals. In addition, he points out that individuals who are concerned with power have desire to influence and direct other. They tend to have control over others and maintain the leader -follower relations. Seen as agents of change as they desire to bring a difference in life, the organization needs to tap in that energy to move the business forward (Friebel, Heinz, \& Zubanov, 2016). These are the individuals who should be included at the decision-making stage and therefore owning the project. Finally, McClelland (2015) noted that, individuals who have higher need for affiliation tend to establish and maintain friendly and warm relations with others. Such people have strong desire for acceptance and approval. They try to adhere to rules of these people whose attention they seek. Other people's feelings are their priority. For the firm to succeed, such individuals need to put in positions of low ranks as they work better under others. Their strength is togetherness and therefore for them to perform better, they must be left to work with others in unity.

\section{Expectancy Theory}

According to Parijat \& Bagga (2014), people tend to work harder when they are properly remunerated. In this case there should be close relationship between the efforts made by a worker and his pay. This normally makes employees to form trade unions to advocate for better pay. He holds that the rewards that employees get will determine how motivated he is and this directly impacts on the organizations performance. Satisfied workers will improve performance in terms of quality and quantity. Weller, Castanelli, Chen, \& Jolly, (2017) agrees more with Parijat \& Bagga (2014) that a fair balance should be struck between an employee's input and employees output in which effort and salary should match. Individual employees behave according to how they are motivated and this influence the outcome of the organization either positively or negatively, for instant choices made by employees based on estimates of how well the expected outcome of a given behavior should match the expected result (Friebel, Heinz, \& Zubanov, 2016).

\section{Methodology}

\section{Research Design}

In this analysis, a quantitative research design is used to unveil some of the answer to the research topic. Accordingly, the researcher has used descriptive study design to not only explore the features 
INTERNATIONAL JOURNAL OF ACADEMIC RESEARCH IN BUSINESS AND SOCIAL SCIENCES Vol. 8, No. 7, July 2018, E-ISSN: 2222-6990 @ 2018 HRMARS

of the informal groups in an organization but also investigate how they affect the performance of the employees within the organization. To effectively gather the data, questionnaires were used in collecting the data on the perceptions the 48 participants had on the notion of informal groups in relation to the productivity of the employees in Philadelphia Pharmaceuticals. The major statistical technique that has been used in this analysis is the descriptive statistics such as frequencies which tried to explicate the very meaning of the data collected form the company.

\section{Data and Sampling}

A total of 72 respondents were sought for this exercise of data collection. The respondents here were those workers employed by Philadelphia Pharmaceuticals. Most of the employees sought for this investigation were from top level management and supervisors across the organization. Stratified sampling technique was used to get a sample of 48 respondents. Apart from questionnaires being sent to them, semi structured interviews were also carried out after getting informed consent from the institution. The data presented below are the distribution of the respondents by sex.

\begin{tabular}{lrr}
\hline & Table 1.0: Distribution of Respondents by Sex & \\
Frequency (Number) & & Frequency (\%) \\
Female & 23 & $47.92 \%$ \\
Male & 25 & $52.08 \%$ \\
& 48 & $100.00 \%$ \\
\hline
\end{tabular}

From the above table, about $48 \%$ of the respondents are female while the male respondents are approximately $52 \%$. The data here is therefore deemed not have any gender bias. From the 48 questionnaires sent to the participants, all the 48 of them were filled hence the response rates was $100 \%$ since the institution was duly informed of the research to be conducted among its employees.

\section{Data Analysis}

Data analysis was done using descriptive statistics and graphical presentation. In the first instance, the reasons for engaging in informal groups were investigated with keen attention to the how these engagements affects the productivity of the firm. Additionally, the data collected enabled the investigation into the very context of informal groups in terms of its characteristics and how the employee felt about belonging to one. Lastly, through calculation of percentages, the effect of informal groups on employee performance was investigated basing the argument on whether it positively or negatively affects productivity.

\section{Results and Discussion Introduction}

This section unveils some of the results brought forward in this investigation to answer how the productivity of the staff of Philadelphia Pharmaceuticals is affected by the inception of informal groups. The results are discussed in three folds which include the reasons for engaging in informal groups, the characteristics of informal groups and the effects of such groups on employee productivity.

\section{RQ1: Reasons for Engaging In Informal Groups}

The chart below shows some of the major reasons why the workforce in Philadelphia engage in informal groups as per the analysis of the questionnaires. 
INTERNATIONAL JOURNAL OF ACADEMIC RESEARCH IN BUSINESS AND SOCIAL SCIENCES Vol. 8, No. 7, July 2018, E-ISSN: 2222-6990 @ 2018 HRMARS

\section{Chart 1.0: Reasons for Engaging In Informal Groups}

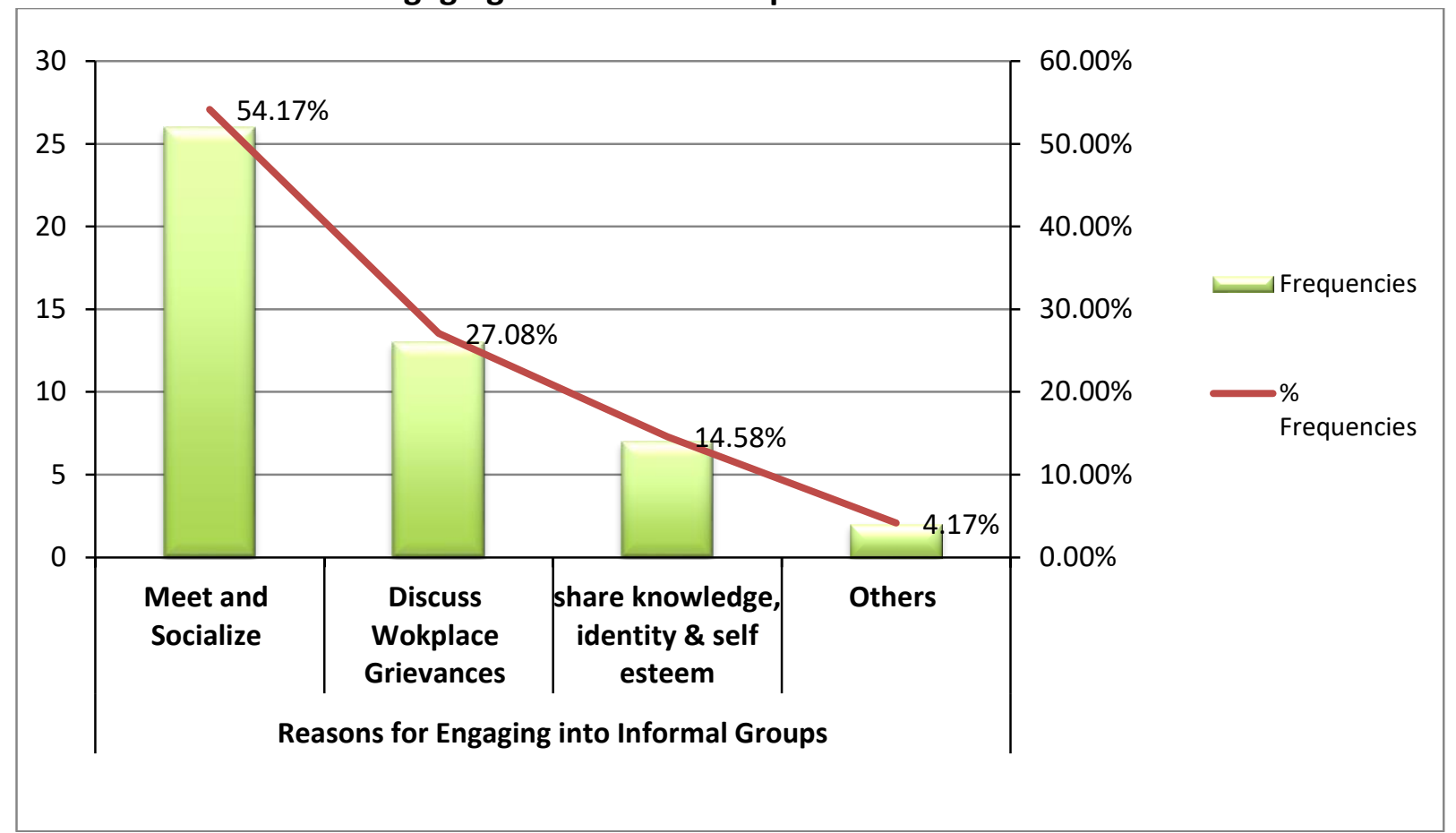

From the above chart, the major aim for the engaging informal groups is to meet and socialize which has the highest score of $54.17 \%$. This reason is followed by discussion of workplace problems and grievances which has a score of $27 \%$. Most of the respondents of Philadelphia Pharmaceuticals were keen to not that when they meet and socialize; they tend to understand each other the more. The understanding here transcends from knowing ones moods and personality traits to getting informed on the best way they can be treated and handled to ensure high productivity within the firm (Kohli, Blitzer, Lefco, Barter, Haynes, Colalillo, \& Zink, 2018). Additionally, on the account of explication of the workplace grievances, the managers would have the opportunity to not only understand how best they can deal with such grievances but will also provide a platform for forging a plan which would be substantial in improving the performance status of the firm.

The sharing of knowledge and improvement of self-esteem which as a score of $14 \%$ points out to the fact that indeed, there is a lot that could be gained from having informal groups. Weller, Castanelli, Chen \& Jolly (2017) noted that it is through inception of informal groups that the issue of interprofessional collaboration came on board. Through inter-professional collaboration, one of the managers asserted that they have shared knowledge, challenges, experiences and expertise on the various work procedures and found out that a collective brainstorming about a procedure is usually the best way to solve a problem. Therefore, according to the chart 1.0 above, engaging in informal groups not only enhances the level of communication through meeting and socializing but it also encourages the inter-professional collaboration which indeed have a positive impact on the performance of the firm.

\section{RQ2: Characteristics of Informal Groups}

From the analysis of the data collected from the questionnaires, the chart below has been summarized to help understand some of the pertinent features of informal groups in this company's management setting. 
INTERNATIONAL JOURNAL OF ACADEMIC RESEARCH IN BUSINESS AND SOCIAL SCIENCES Vol. 8, No. 7, July 2018, E-ISSN: 2222-6990 @ 2018 HRMARS

\section{Chart 2.0 Characteristics of Informal Groups}

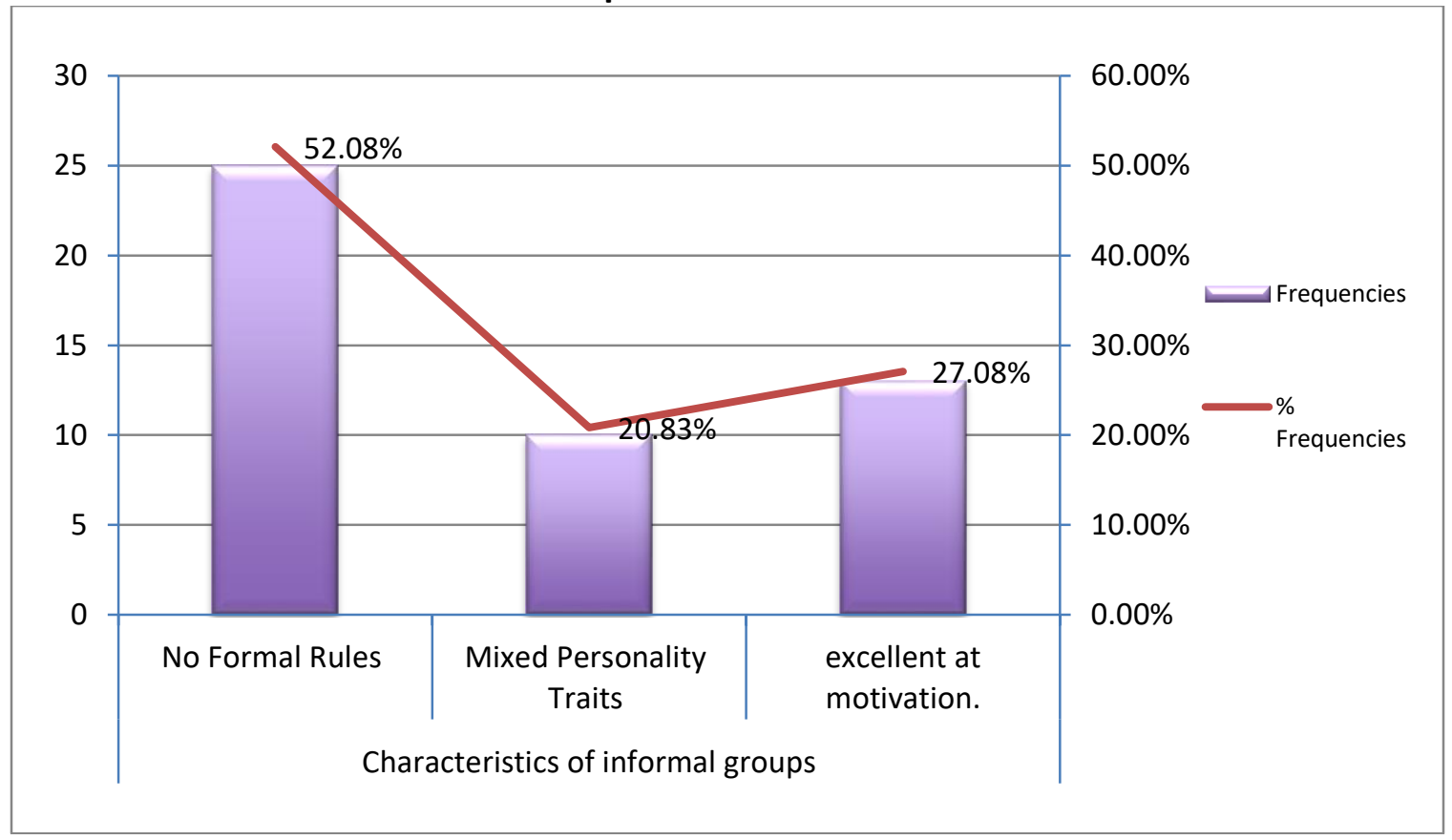

From the 48 participants investigated, $52 \%$ of them noted that informal groups have no official rules of engagement hence every individual is entitled to their opinion. This statistics shows that in informal groups, there is high level of autonomy in which every group member views the other as equal and would give impartial opinions about their actions within the group. Informal groups therefore create a platform where every member is given equal chance to express their views and perspectives over a particular course of action. From the chart, $27.08 \%$ of the respondents see informal groups as a platform for excellent motivation within the formal sector of the institution. Weller, Castanelli, Chen \& Jolly (2017) asserts that through autonomous thinking, the employees are given the platform to deliberate on issues that affect them and plainly ask for a way to deal such infirmities. Through sharing of one's experience, the staff is able to get informed solution on how to deal with both their social and work related issues. In so doing, the whole-some growth of the employee would be exemplified in the best way possible (Brown, Gray, McHardy, \& Taylor, 2015). The fact that there are mixed personalities within informal groups makes it even better to have a good interactive platform where every individual has the opportunity to encourage each other in setting attainable goals and accomplishing them be it informal or work-related. Intrinsic motivation comes from informal groupings through understanding one another and coming up with ways to tackle every challenging situation in a collaborative manner (Lloyd, \& Mertens, 2018).

\section{RQ3: Impact of Informal Groups on Productivity}

To understand the impact of informal groups on productivity of the Philadelphia Pharmaceuticals workers, the survey carried entailed noting down the opinion of the employees on whether they think informal groupings have a positive effect on the productivity. The results of the data are as summarized in the chart below 
INTERNATIONAL JOURNAL OF ACADEMIC RESEARCH IN BUSINESS AND SOCIAL SCIENCES Vol. 8, No. 7, July 2018, E-ISSN: 2222-6990 @ 2018 HRMARS

\section{Chart 3.0 Effects of Informal Groups on Productivity}

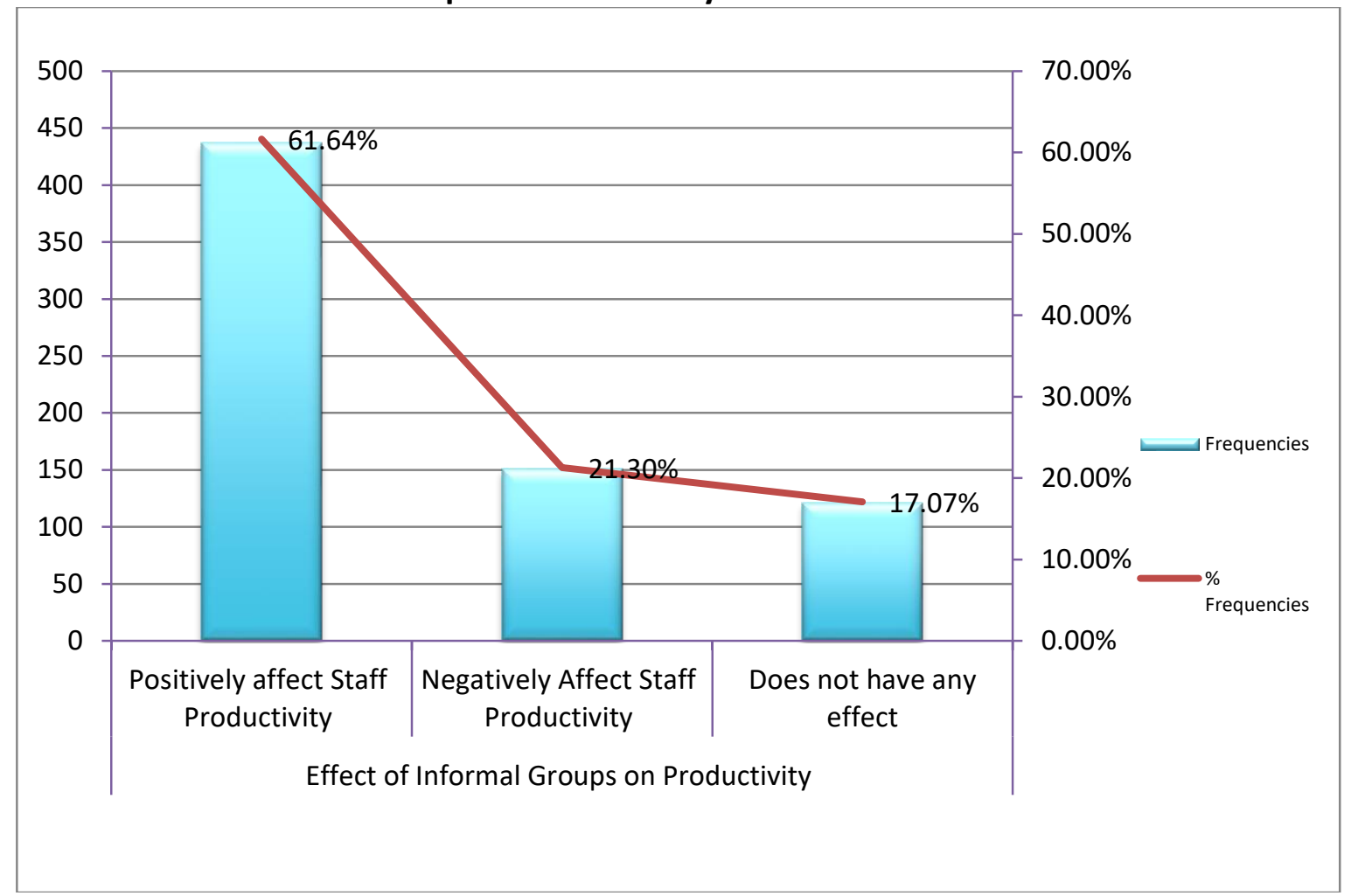

From the chart above, it is evident that a huge percentage of the respondents noted a positive impact of informal groups on productivity. It should be noted that almost $92 \%$ of the employees in this organization belong to an informal organization. This sample of respondents indeed confirmed the high level of productivity that they experience when they engage in informal settings with their colleagues. Through semi-structured interviews, it came out clearly that these employees valued informal groups such as trade unions since they feel having a sense of belonging to a society that ensures that justice is done to the workers across the board (Lloyd, \& Mertens, 2018). Additionally, $78 \%$ of them noted they feel quite secure financially and emotionally when they join informal financial groups that give them advice on how best they can utilize their salary without strain. Instinctively, the role of management in utilizing the informal grouping platform has been welldefined with $82 \%$ of the respondents giving credit to informal group as the pioneer for interprofessional collaboration. From the analysis as per the chart, $21.3 \%$ of the respondents insisted on informal groups having a negative impact on the productivity of the employees within Philadelphia Pharmaceuticals Company management framework (Hall, Frink, \& Buckley, 2017). One of the glaring reasons for the lower productivity is the kind of backup these employees get from the informal groups such as unions. These respondents noted that indeed such vibrant unions might make the employees have constant strikes which might impede the very productivity of such companies. In coming up with strategies to reduce the number of strikes within the institution, Philadelphia Pharmaceuticals Company has tried to lobby with the employee in such a way that they have a collective bargaining agreement without the involvement of the informal groups that might disrupt the very context of efficiency in operations within this management framework (Van den Broeck, Ferris, Chang, \& Rosen, 2016). Among these respondents, $89.67 \%$ confirmed that the use of collective bargaining agreements within the company is the best strategy that would ensure the employees come to compromise in terms of productivity that would eventually improve on the performance of the firm. 
INTERNATIONAL JOURNAL OF ACADEMIC RESEARCH IN BUSINESS AND SOCIAL SCIENCES Vol. 8, No. 7, July 2018, E-ISSN: 2222-6990 @ 2018 HRMARS

\section{Conclusion and Recommendations}

The major objective of this analysis was to understand the actual impact of informal groups on the productivity of employees within a management framework. This descriptive study research study confirmed the fact that some of the major reasons why people engage in informal grouping are such as to meet and socialize (54\%), to discuss their grievances at workplace $(27 \%)$ and to share knowledge, self-esteem and identity (14\%) among others. From the perspective of the analysis, the Philadelphia Pharmaceuticals employees questioned confirmed that indeed there is high level of performance that has been recorded since the inception of various informal groups within the firm. This notion has indeed been strengthened by the literature and theoretical analysis done in this excerpt which points out to the fact that there is indeed a positive relationship between productivity and informal group engagement by workers. It is therefore important to encourage the informal groups within the firm in order to not only create an advent of autonomy in the company but also to help cope up with the very challenges that effects the employees productivity that emanates from the social arena.

After a critical look into characteristics of informal groups, the respondents noted that one of them is that there are no rules. The fact that there are no rules provides a critical platform for autonomy for the employees which would allow them to express their challenges in the best way possible. The potential capabilities of these employees would be improved when exposed to such informal setting which allows them to be self-directed. Accordingly, it would be assumed that a proper management framework would be achieved through inculcation of the informal groups into this framework. The results also showed that informal groups, forms the basis for an excellent motivation hence Philadelphia Pharmaceutical Company should use the informal groupings platform to ensure that their workforce is improved.

From this investigation, it is recommended that employee involvement in informal groups should be allowed within an organizational context. This move will not only allow high level of autonomy within the workplace but it will also bring on board high motivation within the work which will eventually improve on productivity of the workforce. It is also recommended that such informal groups should be controlled through inception of a profound set of rules and regulation which would allow for proper running of the same. This way, issues to do with strikes within the employment sector would be reduced accordingly creating a high level of sanity in the running of such informal groups.

\section{References}

Barends, E., Janssen, B., \& Velghe, C. (2016). Technical report: Rapid evidence assessment of the research literature on the effect of goal setting on workplace performance.(pp. 1-19). London: Chartered Institute of Personnel and Development (CIPD). See here.

Brown, S., Gray, D., McHardy, J., \& Taylor, K. (2015). Employee trust and workplace performance. Journal of Economic Behavior \& Organization, 116, 361-378.

Cheavens, J. S., Cukrowicz, K. C., Hansen, R., \& Mitchell, S. M. (2016). Incorporating resilience factors into the interpersonal theory of suicide: The role of hope and self-forgiveness in an older adult sample. Journal of clinical psychology, 72(1), 58-69.

De Vito, L., Brown, A., Bannister, B., Cianci, M., \& Mujtaba, B. G. (2018). Employee motivation based on the hierarchy of needs, expectancy and the two-factor theories applied with higher education employees. IJAMEE.

Dweck, C. S. (2017). From needs to goals and representations: Foundations for a unified theory of motivation, personality, and development. Psychological review, 124(6), 689. 
INTERNATIONAL JOURNAL OF ACADEMIC RESEARCH IN BUSINESS AND SOCIAL SCIENCES Vol. 8, No. 7, July 2018, E-ISSN: 2222-6990 @ 2018 HRMARS

Friebel, G., Heinz, M., \& Zubanov, N. (2016). The Effect of Announced Downsizing on Workplace Performance: Evidence from a Retail Chain.

Hall, A. T., Frink, D. D., \& Buckley, M. R. (2017). An accountability account: A review and synthesis of the theoretical and empirical research on felt accountability. Journal of Organizational Behavior, 38(2), 204-224.

Harris, T. E., \& Sherblom, J. C. (2018). Small group and team communication. Waveland Press. Hughes, M., Rigtering, J. C., Covin, J. G., Bouncken, R. B., \& Kraus, S. (2018). Innovative Behaviour, Trust and Perceived Workplace Performance. British Journal of Management.

Jackson, D. (2018). Challenges and strategies for assessing student workplace performance during work-integrated learning. Assessment \& Evaluation in Higher Education, 43(4), 555-570.

Kohli, A., Blitzer, D. N., Lefco, R. W., Barter, J. W., Haynes, M. R., Colalillo, S. A., ... \& Zink, C. F. (2018). Using Expectancy Theory to quantitatively dissociate the neural representation of motivation from its influential factors in the human brain: An fMRI study. Neurolmage.

Kukenberger, M. R., Mathieu, J. E., \& Ruddy, T. (2015). A cross-level test of empowerment and process influences on members' informal learning and team commitment. Journal of Management, 41(3), 987-1016.

Lloyd, R., \& Mertens, D. (2018). Expecting More Out of Expectancy Theory: History Urges Inclusion of the Social Context. International Management Review, 14(1).

Locke, E. A. (2015). Theory building, replication, and behavioral priming: Where do we need to go from here?. Perspectives on Psychological Science, 10(3), 408-414.

Ma, J., Batterham, P. J., Calear, A. L., \& Han, J. (2016). A systematic review of the predictions of the Interpersonal-Psychological Theory of Suicidal Behavior. Clinical psychology review, 46, 3445.

Marsick, V., \& Watkins, K. (2015). Informal and incidental learning in the workplace (Routledge revivals). Routledge.

McClelland, D. C. (2015). Achievement motivation theory. Organizational behavior, 1, 46-60.

Mueller, J. (2015). Formal and informal practices of knowledge sharing between project teams and enacted cultural characteristics. Project Management Journal, 46(1), 53-68.

Parijat, P., \& Bagga, S. (2014). Victor Vroom's expectancy theory of motivation-An evaluation. International Research Journal of Business and Management, 7(9), 1-8.

Peacock, J. (2015). Gamification as a Means of Workplace Performance Improvement.

Thibaut, J. W. (2017). The social psychology of groups. Routledge.

Van den Broeck, A., Ferris, D. L., Chang, C. H., \& Rosen, C. C. (2016). A review of self-determination theory's basic psychological needs at work. Journal of Management, 42(5), 1195-1229.

Weller, J. M., Castanelli, D. J., Chen, Y., \& Jolly, B. (2017). Making robust assessments of specialist trainees' workplace performance. British journal of anaesthesia, 118(2), 207-214. 
INTERNATIONAL JOURNAL OF ACADEMIC RESEARCH IN BUSINESS AND SOCIAL SCIENCES

Vol. 8, No. 7, July 2018, E-ISSN: 2222-6990 @ 2018 HRMARS

\section{APPENDICES}

Questionnaires Results

\section{Reasons for Engaging into Informal Groups}

\begin{tabular}{|c|c|c|c|c|}
\hline \multicolumn{5}{|c|}{ Reasons for Engaging into Informal Groups } \\
\hline $\begin{array}{l}\text { Participant } \\
\text { ID }\end{array}$ & $\begin{array}{l}\text { Meet and } \\
\text { Socialize }\end{array}$ & $\begin{array}{l}\text { Discuss Workplace } \\
\text { Grievances }\end{array}$ & $\begin{array}{l}\text { share knowledge, identity \& self } \\
\text { esteem }\end{array}$ & $\begin{array}{l}\text { Other } \\
\mathrm{s}\end{array}$ \\
\hline P1 & 1 & 0 & 0 & 0 \\
\hline $\mathbf{P 2}$ & 1 & 0 & 0 & 0 \\
\hline P3 & 1 & 0 & 0 & 0 \\
\hline P4 & 1 & 0 & 0 & 0 \\
\hline P5 & 1 & 0 & 0 & 0 \\
\hline P6 & 1 & 0 & 0 & 0 \\
\hline P7 & 0 & 0 & 1 & 0 \\
\hline P8 & 1 & 0 & 0 & 0 \\
\hline P9 & 0 & 0 & 1 & 0 \\
\hline P10 & 0 & 0 & 0 & 1 \\
\hline P11 & 0 & 0 & 1 & 0 \\
\hline P12 & 1 & 0 & 0 & 0 \\
\hline P13 & 0 & 0 & 1 & 0 \\
\hline P14 & 1 & 0 & 0 & 0 \\
\hline P15 & 0 & 1 & 0 & 0 \\
\hline P16 & 0 & 1 & 0 & 0 \\
\hline P17 & 0 & 1 & 0 & 0 \\
\hline P18 & 0 & 1 & 0 & 0 \\
\hline P19 & 0 & 0 & 0 & 1 \\
\hline P20 & 0 & 1 & 0 & 0 \\
\hline P21 & 1 & 0 & 0 & 0 \\
\hline P22 & 1 & 0 & 0 & 0 \\
\hline P23 & 1 & 0 & 0 & 0 \\
\hline P24 & 1 & 0 & 0 & 0 \\
\hline P25 & 0 & 1 & 0 & 0 \\
\hline P26 & 0 & 1 & 0 & 0 \\
\hline P27 & 1 & 0 & 0 & 0 \\
\hline P28 & 0 & 0 & 1 & 0 \\
\hline P29 & 0 & 1 & 0 & 0 \\
\hline P30 & 0 & 1 & 0 & 0 \\
\hline P31 & 1 & 0 & 0 & 0 \\
\hline P32 & 0 & 0 & 1 & 0 \\
\hline P33 & 1 & 0 & 0 & 0 \\
\hline P34 & 1 & 0 & 0 & 0 \\
\hline P35 & 1 & 0 & 0 & 0 \\
\hline P36 & 1 & 0 & 0 & 0 \\
\hline
\end{tabular}


INTERNATIONAL JOURNAL OF ACADEMIC RESEARCH IN BUSINESS AND SOCIAL SCIENCES Vol. 8, No. 7, July 2018, E-ISSN: 2222-6990 @ 2018 HRMARS

\begin{tabular}{|c|c|c|c|c|}
\hline P37 & 0 & 0 & 1 & 0 \\
\hline P38 & 1 & 0 & 0 & 0 \\
\hline P39 & 1 & 0 & 0 & 0 \\
\hline P40 & 0 & 1 & 0 & 0 \\
\hline P41 & 1 & 0 & 0 & 0 \\
\hline P42 & 0 & 1 & 0 & 0 \\
\hline P43 & 1 & 0 & 0 & 0 \\
\hline P44 & 1 & 0 & 0 & 0 \\
\hline P45 & 1 & 0 & 0 & 0 \\
\hline P46 & 0 & 1 & 0 & 0 \\
\hline P47 & 1 & 0 & 0 & 0 \\
\hline \multirow[t]{3}{*}{ P48 } & 0 & 1 & 0 & 0 \\
\hline & \multicolumn{4}{|c|}{ Reasons for Engaging into Informal Groups } \\
\hline & $\begin{array}{l}\text { Meet and } \\
\text { Socialize }\end{array}$ & $\begin{array}{l}\text { Discuss Workplace } \\
\text { Grievances }\end{array}$ & $\begin{array}{l}\text { share knowledge, identity \& self } \\
\text { esteem }\end{array}$ & $\begin{array}{l}\text { Other } \\
\text { s }\end{array}$ \\
\hline Frequencie & 26 & 13 & 7 & 2 \\
\hline \multicolumn{5}{|l|}{ s } \\
\hline$\%$ & $54.17 \%$ & $27.08 \%$ & $14.58 \%$ & $4.17 \%$ \\
\hline \multicolumn{5}{|l|}{ Frequencie } \\
\hline S & & & & \\
\hline
\end{tabular}

Effect of Employee performance on Productivity

\begin{tabular}{lrrr}
\hline \multicolumn{2}{c}{$\begin{array}{c}\text { Effect of Employe performance on Productivity } \\
\text { Positively affect Staff } \\
\text { Productivity }\end{array}$} & $\begin{array}{l}\text { Negatively Affect Staff } \\
\text { Productivity }\end{array}$ & $\begin{array}{c}\text { Does not have any } \\
\text { effect }\end{array}$ \\
P1 & 6 & 2 & 4 \\
P2 & 8 & 2 & 1 \\
P3 & 9 & 2 & 1 \\
P4 & 10 & 7 & 1 \\
P5 & 9 & 2 & 1 \\
P6 & 9 & 7 & 1 \\
P7 & 10 & 6 & 1 \\
P8 & 8 & 4 & 1 \\
P9 & 9 & 2 & 1 \\
P10 & 10 & 2 & 1 \\
P11 & 9 & 2 & 1 \\
P12 & 10 & 5 & 1 \\
P13 & 9 & 7 & 4 \\
P14 & 9 & 4 & 1 \\
P15 & 10 & 2 & 1 \\
P16 & 9 & 2 & 8 \\
P17 & 7 & 5 & 7 \\
\hline
\end{tabular}


INTERNATIONAL JOURNAL OF ACADEMIC RESEARCH IN BUSINESS AND SOCIAL SCIENCES Vol. 8, No. 7, July 2018, E-ISSN: 2222-6990 @ 2018 HRMARS

\begin{tabular}{|c|c|c|c|}
\hline P18 & 9 & 2 & 1 \\
\hline P19 & 10 & 5 & 1 \\
\hline P20 & 9 & 2 & 1 \\
\hline P21 & 9 & 2 & 1 \\
\hline P22 & 10 & 2 & 1 \\
\hline P23 & 9 & 8 & 6 \\
\hline P24 & 9 & 5 & 1 \\
\hline P25 & 7 & 5 & 6 \\
\hline P26 & 10 & 4 & 1 \\
\hline P27 & 9 & 4 & 8 \\
\hline P28 & 8 & 2 & 4 \\
\hline P29 & 9 & 2 & 6 \\
\hline P30 & 8 & 2 & 1 \\
\hline P31 & 10 & 2 & 1 \\
\hline P32 & 10 & 2 & 4 \\
\hline P33 & 10 & 2 & 1 \\
\hline P34 & 10 & 2 & 8 \\
\hline P35 & 10 & 2 & 1 \\
\hline P36 & 10 & 2 & 1 \\
\hline P37 & 10 & 2 & 1 \\
\hline P38 & 10 & 4 & 8 \\
\hline P39 & 9 & 2 & 6 \\
\hline P40 & 9 & 4 & 1 \\
\hline P41 & 9 & 2 & 4 \\
\hline P42 & 9 & 2 & 1 \\
\hline P43 & 9 & 2 & 4 \\
\hline P44 & 10 & 2 & 1 \\
\hline P45 & 8 & 2 & 1 \\
\hline P46 & 9 & 2 & 2 \\
\hline P47 & 8 & 2 & 1 \\
\hline \multirow[t]{3}{*}{ P48 } & 10 & 5 & 1 \\
\hline & \multicolumn{3}{|c|}{ Effect of Informal Groups on Productivity } \\
\hline & $\begin{array}{l}\text { Positively affect Staff } \\
\text { Productivity }\end{array}$ & $\begin{array}{l}\text { Negatively Affect Staff } \\
\text { Productivity }\end{array}$ & $\begin{array}{l}\text { Does not have any } \\
\text { effect }\end{array}$ \\
\hline Frequencies & 437 & 151 & 121 \\
\hline$\%$ & $61.64 \%$ & $21.30 \%$ & $17.07 \%$ \\
\hline Frequencies & & & \\
\hline
\end{tabular}

